\title{
From Religious Heritage to Cultural Heritage: Study the Heritage of Buddhism in Vietnam
}

\author{
Vu Hong Van \\ University of Transport and Communications, Vietnam
}

\begin{abstract}
In history and the present, Buddhism holds an important position in the spiritual life of Vietnamese people. For about two thousand years of existence and development with the Vietnamese people, Buddhism has left many valuable (tangible and intangible) heritage, has contributed a significant part in creating the cultural values of the nation. This research focuses on analyzing how did Buddhism creates heritages, how that Buddhism religion heritage becomes the cultural heritage of the Vietnamese people, the values that Buddhism religious heritage contributed to the culture of Vietnam.
\end{abstract}

Keywords: Heritage of Buddhism, religious heritage, tangible cultural heritage, intangible cultural heritage, Vietnam

\section{Introduction}

Buddhism was spread to Vietnam very early. Regarding the specific time, there is still no historical document to determine the exact time when Buddhism came to Vietnam. There are conflicting theories regarding whether Buddhism first reached Vietnam during the 3rd or 2nd century BCE via delegations from India (Lang, N 1974) or during the 1st or 2nd century from China (Giau, TV 1973; Thu, NT 2008). Discussing this issue because of the view that in fact, Buddhism in Vietnam was Buddhism in Chinese colors, because Buddhism was spread into China before being spread into Vietnam. In either case, by the end of the second century CE, Vietnam had developed into a major regional Mahayana Buddhist center centering on Luy Lau ${ }^{1}$, northeast of the present-day capital city of Hanoi. Luy Lau was the capital of the Han region of Jiaozhi and was a popular place visited by many Indian Buddhist missionary monks en route to China. The monks followed the maritime trade route from the Indian sub-continent to China used by Indian traders (Giau, TV 1973, p. 487).

Buddhism in Luy Lau with the center at Dau pagoda had a significant impact on the thinkers of Lac Viet. "When Buddhism was peacefully introduced into Vietnam, with the compassionate and selfless mindset of Buddhism was quickly absorbed by indigenous people and became the consciousness of the ancient Vietnamese people" (Thuan, NK 2004, p. 70). Lac Viet nation at that time had a wet rice agricultural civilization, but the state and religious organizations were simple.

1 Luy Lau was recorded which was an ancient citadel with a history of 2,000 years old, dating back to the Eastern Han Dynasty (Dai Viet Su Ky Toan Thu 1697). In today's location in Bac Ninh province, for more than 800 years (from the 2 nd century to the Tang dynasty at the beginning of the 9th century AD), Luy Lau was both the headquarters of the northern colonial government and an important center about economic, cultural and religious in Jiaozhi (Dai Viet Su Ky Toan Thu 1697, now northern Vietnam and part of South China. In order to prove Luy Lau's role as the center of Buddhism (Quang, T. \& An, T 2019), "archaeologists have discovered tile-top heads on which decorated lotus flowers, or human faces, that had who thought these were symbols of Buddhist culture spread directly into Vietnam". "Artifacts like bricks and tiles, or hundreds of brick tombs, prove the life of the mandarins who ruled the Han Dynasty in Jiaozhi” (Quang, T. \& An, T 2019). 
Meanwhile, that country had always been threatened by Northern enemies (Chinese feudal dynasties) and had risk was invaded. Most likely (Giau, TV 1973), Buddhism contributed a part in promoting the ideological role of the Vietnamese against the Chineseization process. "In the Northern domination period, Buddhism did not become a national religion but played a role as a religion of national to participate in protecting the culture and national sovereignty of Vietnamese people" (Tho, HT 2010).

After escaping from the domination of Northern colonialism (the Vietnamese call this period has been the Northern domination period), since the 10th century, Vietnam has entered the era of independence and autonomy, Buddhism had did not cease development. The Dinh and Tien Le Dynasties, the court began to employ some monks with profound knowledge in many fields. The Dinh and Tien Le Dynasties issued several patronage policies and developed the Buddhist Sangha system throughout the country as an orthodox religion, many large pagodas were built right at the Imperial city (Giau, TV 1973; Thu, NT 2008; Dai Viet Su ky Toan Thu 1697). The kings of Ly and Tran Dynasties also sent delegations to China to get Buddhist scriptures to print and spread to the people, "making the octagonal house contain Buddhist scriptures" (Dai Viet Su Ky Toan Thu 1697, p. 256). "Buddhism in this period began to play its role as a spiritual force of the nation in strategic ways of building and stabilizing the country after a long period of being colonized" (Tho, HT 2010).

An important mark in the field of the religion of the Ly Dynasty was the flourishing of Buddhism. In the Ly Dynasty, Buddhism became the state religion of the Dai Viet state. The Ly Dynasty survived more than 200 years (1009-1225) with nine kings (Dai Viet Su Ky Toan Thu 1697). In Vietnamese history, the Ly Dynasty was great and left many deep imprints in different fields. The Ly Dynasty promoted Buddhism due to many causes. In terms of relations, the king established the Ly Dynasty with a special relationship with the contemporary monks, he was once adopted children of the monk Ly Khanh Van and a disciple of monk Van Hanh (Tu Dao Hanh). In terms of religious beliefs, Kings of the Ly Dynasty were very devout Buddhists. "On royal holidays, the king goes to Chan Giao pagoda so that the king could sit and watch chanting" (Dai Viet Su Ky Toan Thu 1697, p. 257). Some kings themselves were honored as the ancestors of the Buddhist sects. King Ly Thai Tong was the seventh ancestral of the Vo Ngon Thong Zen sect, King Ly Thanh Tong was the second ancestral of Thao Duong Zen sect. In this period, Buddhism was not only for monks and Buddhists but also affect the whole society (Thuan, NK 2004). In every village of the Dai Viet, there were pagodas in the village. The pagoda was the sacred place of the people of the village, where people send their thoughts, the feelings of myself, the family and of the clan, coming to the pagoda to worship Buddha was the daily work of the people.

Along with the Ly Dynasty, the Tran Dynasty was one of the most prosperous dynasties in the history of feudal Vietnam, also known as one of the periods when Buddhism truly integrated into the heart of the nation (Lang, N 1974). Factors leading to the success of Buddhism in the Tran Dynasty were inseparable from the cause of preserving, building and defending the fatherland. Buddhism has really been penetrating for a long time and over many centuries has been adapted to Vietnamese customs, beliefs, and people. Under the Tran Dynasty, Buddhism became the "essence" and integrated into the national culture, speaking in the Buddhism way as "water with milk" (Nguyen, $P$ 2019). Many large-scale pagodas, towers were built during this period such as Pho Minh pagoda, Binh Son tower, Boi Khe pagoda, Thai Lac pagoda, etc which has still existed to today. The Tran 
Dynasty formed a Zen sect that was the Truc Lam Zen sect, a very specific sect of Vietnam (Dai Viet Su Ky Toan Thu 1697).

After the peak of the reign of the Ly Dynasty and the Tran Dynasty, to the Le Dynasty and the Nguyen Dynasty, Buddhism "gave way" to Confucianism. Buddhism was no longer used by kings of the Le Dynasty and the Nguyen Dynasty (Giau, TV 1973). Buddhism returns to its starting point of influencing folk (Thuan, NK 2004). But it was in this familiar "land" that Buddhism created other values (Lang, N 1974). Buddhism was no longer the religion of the court, of kings, it was the religion of the people.

In the process of existence and development in Vietnam, Buddhism has left many tangible and intangible heritages. Many large-scale pagodas that were built under the feudal dynasties of Vietnam still exist today. Many woodblocks of Buddhist scriptures have been recognized by UNESCO as a world document heritage. Many Buddhism festivals have been held every year, especially in the spring (three months after the Vietnamese Lunar New Year) with the participation of thousands of people. The teachings of Buddhism have been "deeply ingrained", "rooted" in the spiritual life of the Vietnamese people. Many famous monks in the history of the nation were worshiped and revered by generations of Vietnamese people. All of these have created a very rich Buddhism heritage, becoming an inseparable part of Vietnamese culture.

\section{Buddhist Heritage in Vietnam}

\subsection{Tangible Heritage}

The pagodas system:

If we go all over Vietnam, we will notice that in any village of Vietnam there is a Buddhism pagoda. The size of these pagodas is different. There are small-scale pagodas of several thousand meters with two or three buildings, but there are big pagodas of dozens of hectares with hundreds of large and small buildings. There is a special thing, these pagodas are built in areas with very beautiful scenery, and have mountains, rivers or areas with many trees.

In Vietnam, up to the present time, there has not been any specific statistics on the number of temples, the size of each temple. The most recent statistic is that Vietnam Buddhist Sangha was published in the Annual Conference of the Central Administration Council (December 26 and 27, 2003) held at Quang Duc pagoda (Ho Chi Minh City) is 14.401 pagodas. According to statistics of the Department of Cultural Heritage, Ministry of Culture, Sports and Tourism of Vietnam, as of 2012, there were 788 pagodas ranked as national monuments out of 3,374 monuments of the whole country.

Studying the system of pagodas in Vietnam, through ancient documents, epitaphs and ordained documents by feudal dynasties of Vietnam still stored in pagodas, it is realized that there are two types of pagodas: Firstly, the pagoda was built by the court. These pagodas often had a very large scale and often were built in places that were very beautiful (there were mountains, rivers, forests, etc.). Secondly, the pagodas were built by villagers. These pagodas were built right in the 
village land. These pagodas were usually small in scale. However, the land was selected for building the pagoda must match the village's feng shui ${ }^{2}$.

For the first type of pagodas: As analyzed above, the Ly and Tran Dynasties were very devout Buddhism, so under these two Dynasties, the pagoda was also built the most. It was the kings who ordered the building of the pagodas (Dai Viet Su Ky Toan Thu 1697), many famous pagodas in history both in scale, architecture and holiness built under the Ly and Tran Dynasties which have persisted to this day.

Because the Ly and Tran Dynasties were the periods of the devotion of Buddhism, so in Thang Long capital, apart from the architectural system of palaces, multi-storied houses, the Ly Kings had built many Buddhism architectural works that famous as Ngu Hung Thien pagoda (in 1010), Van Tue pagoda (in 1011), Chan Giao pagoda (in 1024), Dien Huu pagoda (in 1049), etc.

Outside Thang Long capital, the court had also built many large-scale, pagodas worship Buddhism such as Phat Tich pagoda, Dam pagoda (Bac Ninh), Ngo Xa pagoda (Nam Dinh), Long Doi pagoda ( Ha Nam), Tuong Long tower (Hai Phong), etc. Under the Tran Dynasty, Buddhism continued to develop with many large pagoda architectural such as Pho Minh pagoda and tower (Nam Dinh), Binh Son tower (Vinh Phuc). King Tran Nhan Tong who was the devotion to Buddhism, after leaving the throne and retransmit to his son, specialized in research Buddhism studies and founded the famous Truc Lam Zen school in the history of Vietnam (Quang Ninh province today), etc.

Building the pagoda was an important job for kings, and affecting the whole royal dynasty. Therefore, in order to build a pagoda, in addition to choosing a good land position (the left side has a blue dragon, the right side has a white tiger, the back of the pagoda relies on the mountain, in front of the temple gate there must be rivers, lakes flowing through it) (Hinh, ND. 1992). The selection of materials to build the pagoda was also very important. Building materials include greenstone (Thanh Hoa province has the best stone), fired bricks (Bat Trang, Gia Lam, Thang Long) (Hanoi today), ironwood (usually perennial). These were important materials to build the pagoda. When the king had the school owner build pagodas, the localities had must be responsible for finding materials to transfer to the capital.

For the second type of pagoda: In the process of establishing the village and since Buddhism was introduced to Vietnam (3rd century BC) (Vietnam Academy of Social Sciences 1993), besides the image that to be considered Institutions of the village such as banyan tree, water wharf, communal house yard, almost every village had a temple. Vietnamese proverb wrote "king land, village pagoda", most pagodas belongs to the village community. Building pagodas was always a big deal for the Vietnamese village (Chu, PH 1960). The pagoda and the village communal house were typical works of the whole village. Not only was architectural work, but the pagoda has been also a symbol of

2 According to the folk view of Vietnamese people, Feng shui has been the sum of all elements surrounding the human such as topography, the shape of land, rivers, lakes, mountains, graves, the layout of the construction, space, wind direction, and also the relationship between people and people in the villages and hamlets. Feng shui is strongly associated with the prosperity, the bliss, good things, evil things, the longevity of the people, the family, the lineages and even the whole country. 
aspiration of the people. After all the busy living, everybody to pagoda feels peaceful and pure in the soul.

Choosing land to build pagodas was often dominated by the concept of feng shui (Hinh, ND 1999), to build a pagoda, village people had to choose a good land, a good day, a good time. Good land was a place on the left that was empty or had rivers, lakes, and streams; the right must have a mountain (white tiger). The white tiger mountain (or tiger's hand) on the right is high and thick. Rivers and lakes must be winding, and surround pagodas or in the shape of a lotus flower or dragon-shaped, etc.

The pagodas in villages and communes of Vietnam were usually built with familiar materials such as bamboo, wood, bricks, stone, etc (Vietnam Academy of Social Sciences 1993). But the people often give the pagoda the best materials. Materials, as well as money used for the construction of the temple, have had often donated in all of the people, called "merit". The people of the village believed that they would enjoy happiness, peace, health, etc. from offering materials or money for the construction of the pagoda. On wood pillars without termites, some pagodas clearly etched the names of contributors. In addition, these names have had also recorded in stone altars or on crockery, porcelain such as incense bowls, vases, lamp platforms, etc. in a long list.

The first day of building the pagodas as well as the inauguration day were all meaningful moments in the life of the people of the Vietnam countryside. There have had a usually special day during these days such as the village's founding anniversary, the anniversary of the death of a village's tutelary god, the first day of the Lunar New Year, etc.

Vietnamese pagodas were usually not a single building but an architectural complex, consisting of houses arranged side by side or connected (Vietnam Academy of Social Sciences 1993). Depending on the layout of these houses, people divide them into different types of pagodas. However, the village pagoda always has had a temple gate, the main hall worshiping Buddha, the right and the left are two house blocks. These two house blocks are often used to rest or prepare for Buddha worship during the pagoda's major holidays.

From the perspective of Buddhism art architecture, we see that many pagodas deserve to be honored as typical architectural art relics and lively "museums of sculpture". Vietnamese often say: "The pagoda roof protects the soul of the nation". That shows how important and close the Buddha has been to the people of Vietnam. In each pagoda, there has been a Buddhist worship main house with the system of Buddha statues and Bodhisattvas, each of which has been a complete wooden sculpture, arranged in an order to convey the history of Buddhist thought and teachings. Accordingly, standing in front of the Buddha worship main house, all Buddhists can worship and receive much Buddhist knowledge at the same time. The cultural space of the Buddhism pagoda has been quite standard, systematic and synthesized, an organic attachment between architecture, sculpture, painting and natural landscape (pagoda gate, pagoda yard, the main house is to worship Buddha, ancestral house, bell tower, place of worship for the Mother Goddess, etc). For example, Tay Phuong pagoda, Thach Xa commune, Thach That district, Hanoi has been a complex of 3 parallel houses. In particular, the Tay Phuong pagoda has 72 very special Buddha statues. It can be considered as a museum of sculpture in Vietnam. 


\section{Woodblocks of Buddhism Scriptures:}

Along with the pagoda and tower architecture, one of the Buddhism heritage to have become a unique heritage of Vietnam that is the woodblocks of Buddhist scriptures. Currently, there has been no full research on the existence of how many woodblocks of Buddhist scriptures exist in Vietnam, so that there cannot fully appreciate the importance and value of this heritage in the history of the nation. However, only need two blocks of the woodblocks of the Buddhist scriptures at Vinh Nghiem pagoda and Bo Da pagoda showed the great value of it.

The woodblocks are wooden boards reverse engraving used to printing books (Dan, Zhang $\mathrm{Xi}, 1989$ ). According to many ancient document sources, and opinions of researchers (Ab Woodside. 1988; Tinh, DT 2015; Hue, NT 2016); in Vietnam, the method of carving on wood also has a long history, lasting more than a thousand years. The woodblocks that still exist today proved for those statements; that are the woodblocks at Vinh Nghiem pagoda and Bo Da pagoda (Bac Giang province today), the Nguyen Dynasty woodblocks and Truong Luu woodblocks in Ha Tinh (today).

Through actual research at Vinh Nghiem and Bo Da pagodas, the number of woodblocks is very large. In Vinh Nghiem pagoda, the number of woodblocks is nearly 3,000, in Bo Da pagoda the number of woodblocks is nearly 2,000. All of these woodblocks are preserved almost intact. The texts engraved on the woodblocks here were texts of Buddhism scriptures, with the function of transmitting Buddhism scripture from India to Vietnam, including the selected Sutras with quintessential content (Su, N 2016). Most of the Buddhism scripture writings reflect the precepts of the Buddha but were expressed in Nom script in the form of six-syllable verses so that it was easy to remember and understand (Chu, PH 1960). It is easily transmitted from person to person, generation to generation, such as scripture of "Quoc Am Ngu Gioi", "Quoc Am Thap Gioi”, "Uy Nghi Quoc Am" and "Uy Nghi Quoc Ngu", etc. at Vinh Nghiem pagoda; scripture of "Lang Nghiem Chinh Mach", "Yet Ma Hoi Ban", "Nam Hai Ky Quy, etc. at Bo Da pagoda.

To make woodblocks, choosing wood is an important first job (Su, N. 2016). The "Long Muc" tree, also known as the "Thung Muc" tree, the "Nha Dong Moc" tree (Bang, H 1970; Cam, HH 2006), was distributed in some provinces of Central - Highlands of Vietnam. The tree was soaring, straight, and softwood, like white ivory. According to folk experience, in addition to timber, the "Long Muc" tree was also used as folk medicinal plants; all stems, leaves, roots, and flowers were used as medicine. In particular, the wood of the "Long Muc" tree had been used for carving woodblock prints in feudal times, because of the characteristics of softwood, had not the eyes, not warped, cracked, beautiful, light color, etc. had been suitable for sculpture and printing book. The Book "Dai Nam Nhat Thong Chi" (Su, N 2016), compiled under the Nguyen Dynasty states that the wood used for woodblock printing was the "Long Muc" tree, the grain was white and shiny like ivory.

Apart from the wood of the "Long Muc" tree, the wood of the "Thi" tree was also used to make book-making boards. According to the "Chau ban" of the Nguyen Dynasty, under King Tu Duc's reign, the Quoc Su Quan ${ }^{3}$ reported to King Tu Duc about book engraved printing. In the Book

3 The Quoc Su Quan was the agency established under the reign of King Minh Mang (in 1821). This agency had the function of historiography, printing books and preserving documents of the previous dynasties and those of the Nguyen Dynasty (1802 - 1945). 
"Ngu Chi Thi So Tap", the Book "Dai Nam Thuc Luc Chinh Bien" had written: "now check the sample record includes 1,900 pages, need to use 995 wooden planks of the "Thi" tree". Not only wood of the "Thi" tree, wood of the pear tree, wood of apple tree were also used as make plank to print books (Huong, VTM. 2009).

\subsection{Intangible Heritage}

The festival of pagoda: One of the typical intangible heritage of Buddhism is the festival. There are big Buddhism festivals, lasting for months and affecting the whole country such as the Huong pagoda festival (Hanoi today), Yen Tu festival (Quang Ninh province today) Bai Dinh pagoda festival (Ninh Binh province today), Keo pagoda festival (Thai Binh province today), etc. In many localities of Vietnam, the village's pagoda festival is considered the biggest of the year.

The festival of pagoda is held in the spring (the first 3 months of the year according to the Vietnamese lunar calendar) (Anh, T. 2005; Binh, PK. 2005). For Vietnamese agricultural residents, this is a "free time" (farmers do not have to go to the field to work). The Vietnamese proverb said: "Tháng giêng là tháng ăn chơi, tháng hai cờ bạc tháng ba hội hè" (January is the month of entertainment, February is to play chess, and March is to go to festivals); so they have time to go to the temple to worship Buddha, pray for peace, health and wealth. In addition, to the temple festival also to familiarize and make friends. Due to busy year-round work, people do not have time to familiarize themselves and interact with people outside the village, only festivals people have the opportunity to exchange, make friends; especially the young boys and girls. The festival is a place for boys and girls to get acquainted and be able to proceed to marriage. Many have become couples from pagoda festivals. According to Phan Ke Binh (2005), the festival in general and the temple festival is where good things have been sublimated.

Literature of Buddhism: Vietnamese Buddhist literature is a part of world Buddhist literature and is also an important component of Vietnamese literature. It is a massive treasure and scale. It is not only massive and massive in content but also extremely rich in genres and languages; it is one of the main sources, the beginning of erudite literature and writing the literature of Vietnam, with the thought of rescue as a special inspiration (Hai, TT 2002). In terms of genre, Buddhist literature has contributed to national literature with many achievements in the genres of poetry, story, theory, and translation-glossary in both Han and Nom sections (Lang, N 1974).

With such a huge and rich treasure, Buddhist literature has contributed a lot of concepts and words enriching the Vietnamese language, and through the process of translating-annotating, compiling and composing. It has contributed significantly to cultivating the voice, contributing to making Vietnamese a symbolic language that can express aspects of social life and people (Hai, TT 2002). The concepts of Buddhism are no longer specific within the scope of Buddhism, but have come to life, become the voice of the people and moreover, a close material to compose literature and art.

It was not until the Ly and Tran Dynasties that a "Buddhism literature" was present, as some have asserted in an easy (Hai, TT 2002). With a history of more than two thousand years of development and attachment to the nation, Vietnamese Buddhism has a huge literature and the scale that the sketches are just the first step in an effort to introduce it. 
At the beginning of the era, in our country, there were classical classics according to Mahayana Buddhist ideology, which were Buddhists received and sent their conception about life when they translated into Vietnamese language and spread in the folk (Giau, TV 1973, Hinh, ND 2007). These sutras not only serve as a guideline in the spiritual-religious life of the Buddhism but also a theoretical basis for Vietnamese Buddhism in the early stages, to establish the powerful Buddhist ideology, and its effects on literature in particular and national culture, in general, are great (Hai, TT 2002).

Through the development stages of Buddhism (Hai, TT 2002), meeting the requirements of the times, the important ideologies of Buddhism have been introduced into Vietnam. In that context, many works of translation, commentary, essay and literary composition were born, many great literary authors also appeared. Especially since the time of King Tran Nhan Tong with the open Buddhist ideology that he advocated, in the general situation, Buddhist literature has entered many areas of the country's life, both on the literary parts Nom and Han script. In particular, Buddhism literature has made a very important contribution to the formation and development of a section of literature written in the national language (Nom script).

Ethical standards, the way of life of Buddhism: The ethics of Buddhism consists of tightly related precepts, norms, and categories (Lang, N 1974). Buddhism has built a complete moral system from awareness, reasoning to practice and its application to build a good lifestyle. In addition, Buddhism has built up that kind of virtuous person who is compassionate, happy, selfless, nonego and acquires steadfastly on two truths: compassion and wisdom. Buddhist morality has many similarities with the Vietnamese people's morals (Lang, N 1974).

In the process of development in Vietnam, Buddhism did not only conveys the beliefs to people but also plays a part in maintaining social morality. In addition to the points that have been consistent with human emotional morality, Buddhism ethics have had also practiced through affection, belief in life, and belief in the teachings. Therefore, Buddhism's ethical sentiments are absorbed by the Vietnamese, forming a spiritual faith within and dominating their behavior in community relations. Due to observing the moral precepts of Buddhism, Vietnamese people have lived and behaved in a right manner, contributing to making society better and better.

Thought and morality of Buddhism: Can affirm the ideology, ethics are the unique intangible heritage of Buddhism. Thought of "Từ bi" (compassion), "Hi”" (happiness), "Xả" (pardon) of Buddhism are the "medicine" (bai, DV 2019) that makes the morale life more transparent, including the Spirituality life of Buddhists before the pressures of life. Hoang Nhu Mai (2014) once remarked: "If the Buddhism precepts are partly imbued to humanity, then society will reduce how many crimes and life will be better and more harmonious".

The Buddhism philosophy of tolerance, peace, improve and prevention of evil has contributed to awakening people's conscience, enabling people to live in peace, kindness, proactively preventing evil and war threats, ethnic and religious conflicts. In a country, the desire to live peacefully in a peaceful country is only realized when life is built on the moral basis of "selflessness", for each individual to become a member of positive and socially responsible. 


\section{The Process of the Heritage of Buddhism Integrates and becomes the Cultural Heritage of Vietnam.}

\subsection{The Reception and Adaptation of the People}

The compatibility between Buddhism values and Vietnamese cultural values: According to researcher Tran Quoc Vuong (2004), religion is a cultural phenomenon, according to the history of birth and maturity, religion is both a product of culture and a component constituent factors of culture. Ngo Duc Thinh (2014) said that: In the end, every symbolic system of religion and belief is the symbolic system of culture, it contains both the value system of the nation and the expression of the identity and nuances of the nation. In Buddhism, the value system has formed, integrated and preserved many cultural and artistic phenomena with unique national nuances. If you look at the problem systematically, then it is religion and belief that are the core factors that make up that system (including Buddhism ${ }^{4}$ ). And cultural and artistic phenomena are just arising factors. This means that it is impossible to separate the elements of religion, belief and cultural activities attached. Any kind of religion, belief in its essence is never directed to evil but always encourages to do good, reach beauty, greatness for the sake of oneself and of the community (Ngoc, P. 2002).

In the minds of Vietnamese people, a pagoda has been a place expressing the philosophy of human life, the spirit of tolerance and harmony in the religious life of the nation (Ngoc, P 2002). The pagoda meets the needs of rural life, eliminating the inequality gap in community activities in the old village. If in the past, most of the rooms in the communal house were for men, seniors, officials to discuss "village affairs", and women were not allowed to participate, the pagoda was the place for the elderly and women and children followed their grandmother and mother to the pagoda. The folk often has said: "children are happy at home, old people are happy at the pagoda". The pagoda in the village has been usually built in a quiet place, maybe in the corner of the village, along the village or in the center (Lang, NB 1972). But no matter where it has been located in the village, the pagoda has been still presenting both close and mysterious in the spiritual life of the villagers (Duy, ND 1999). Therefore, along with the communal house, the pagoda is also a symbol of the village culture, the origin of the national culture. Venerable Thich Tien Dat, abbot of $\mathrm{Cu}$ Da pagoda, outside Hanoi (2017), said that Buddhism was introduced into Vietnam from the life of the people, so wherever these have been people, have villages, that place has pagodas. The pagoda has become an indispensable cultural institution of the village people (Hinh, 2007). There is a poet who said: "The pagoda roof protects the soul of the nation and the eternal lifestyle of the ancestors". In folklore, it is often said: "Pagoda is ancestral graves of villagers", so the pagoda is considered to be the ancestral tomb of an entire village, of an entire region. The pagoda is not only a place for spiritual activities, beliefs but also a place to send beliefs and desires of the villagers in life. Buddhism advocates compassion and wisdom, directing people towards the truth, the good, the beautiful so that the pagoda is a support spirituality, morale, culture, etc. of people.

Every lunar New Year and spring comes, pagodas often have been festival. There is a pagoda festival that takes place for three months (Huong pagoda festival), there is a pagoda festival that takes place from 1 to 2 month (Yen Tu pagoda and Bai Binh pagoda festivals) (Anh, T 2005). The pagoda festival is a time for all classes of people to come to the Buddha and pray for peace, happiness, health,

\footnotetext{
${ }^{4}$ This is the view of the author.
} 
etc. for their families and for themselves. Going to the pagoda at the beginning of the year has long become a beauty in the spiritual life of Vietnamese people.

Many temples, not only worship Buddha but worship Mother Goddess, so the pagoda festival has been a fusion of religious and open beliefs of Vietnamese people. The special thing is that the pagoda festival is usually held together with the same at time traditional festival of the village. Dai Duc Thich Thong Thuc (2018), who is the head of Na pagoda in Tien Du district, Bac Ninh province (today), said: The pagoda is not only a place of religious activities for Buddhism but every year, villagers often come to the pagoda ceremony at the beginning of the year. After the ceremony at the communal house, the people went to the pagoda to worship the Buddha.

Interestingly, on the traditional festivals of the village is always the meeting between the Village's Tutelary gods, ie the gods of the village have worshiped in the communal house and the Buddha and Mau worshiped at the pagoda. It is a unique point of Vietnamese Buddhism, of Vietnamese culture, so that it can recognize the position of the temple in the village community of Vietnam (Bien, TL 1996, Ngoc, P 2002, Hinh, ND 2007). The pagoda and pagoda festival in the past and present is a living entity, helping generations to understand and understand more about Vietnamese cultural identity.

\subsection{The Role of the Constitutional Dynasties of Vietnam}

As analyzed above, in the history of Vietnam, there were dynasties that worshiped Buddhism, so that the dynasties had many policies to develop Buddhism, namely in the construction of pagodas, casting Buddha statues, "ordination" for the pagoda, appreciating the Zen masters.

The Dai Viet Su Ky Toan (1697) book states: "In the Year of the Goat (1031) King Ly Thai Tong ordered the building of 950 pagodas in the villages and communes of Dai Viet". The pagoda was built much with the purpose of not only disseminating Buddhism scriptures but also a monastery, a forum for Confucian scholars (Giau, TV 1973). Many monks are teachers of princes, be a healer for the people and compose literary works.

There have been many architectural works and sculptures of high artistic value imprinted Buddhist philosophy. The most typical for the Buddhist art at this time are four constructions called "Annam Tu Dai Khi” (Four national treasures of Dai Viet) include: Bao Thien tower, Buddha Maitreya statue in Quynh Lam pagoda, Pho Minh cauldron, Quy Dien bell. In addition, there are many other famous works such as Dien Huu pagoda (One Pillar pagoda), Sung Thien Dien Linh tower, Chuong Son tower, etc. All of these heritage sites were ordered by the Kings Ly and Tran Dynasties.

Historically, many famous monks were respected by feudal dynasties. Recognizing the great role of such Buddhist dignitaries, the Ly Dynasty kings, and the Tran Dynasty kings were always looking for ways to respect and enlist their talents into the cause of developing the country. During the Ly and Tran Dynasty, a series of monks were given the title of the "Quoc Su" (The Chaplain) such as Van Hanh, Vien Chieu, Thong Bien, Vien Thong, and Khong Lo (That, LM 1999). The main role of the Zen Masters of the Ly and Tran Dynasties was to be effective advisers to help the king understand Buddhism's teachings, in addition, when necessary, the Zen Masters also advised the king on political, diplomatic, military issues and culture (Giau, TV 1973). 
The kings of the Ly and the Tran Dynasties often exchanged and discussed with the Zen Masters of Buddhism. Most of the king of Ly and Tran Dynasties always invited famous monks to the palace to the king to discuss the rule of the country, about the spirit of Buddha. Masters Zen: Van Hanh, Da Bao, Giac Hai, Man Giac, Vien Chieu, Quoc Su Minh Khong, Vien Thong, Thong Bien, Phap Loa, etc. did not only glorify Buddhism but also brilliant strategist, support the kings to preserve the royal authority (That, LM 1999). The fact that the Zen Masters were invited by the king to ask about the discuss the rule of the country, itself was not only pure as a work of promoting Buddhism, derived from the devotion of a believer but rather the erudition and wisdom of the monks helped a lot in solving the difficult problems of running the country of the kings.

In the Le and the Nguyen Dynasties, although Buddhism was no longer "important" as the Ly and Tran dynasties, many kings of the Le and Nguyen dynasties still took actions to support Buddhism. Many pagodas have been newly built or "restored" during this period (Lang, N 1974). Many Chinese monks came to the country of "Dang Trong"5 to successfully evangelize such as Vien Canh, Vien Khoan, Hung Lien, Giac Phong, Phap Bao, Tu Dung, etc. The Zen schools thrived at that time. Truc Lam Zen meditation was restored again in the presence of a Vietnamese Zen master who was Huong Hai.

Another thing to mention is that even the Ly and Tran kings themselves were Buddhists. In addition to running the country according to the celestial mandate, the Ly kings also spent time studying Buddhist doctrine, and moreover, they were Buddhists. When the nation needed the ruler, the head of the government, all the duties and duties, when the peaceful country reigned, they returned to the joy of Buddhism. In the book "Thien Uyen Tap Anh" (That, LM 1999) also stated that King Ly Thai Tong was the seventh generation lineage of Vo Ngon Thong sect, King Ly Thanh Tong was the first generation lineage of the Thao Duong sect; King Ly Anh Tong was the third generation lineage of the Thao Duong sect; King Ly Cao Tong was the fifth generation lineage of the Thao Duong sect; King Tran Nhan Tong founded the Truc Lam Zen lineage (Dai Viet Su Ky Toan Thu 1697). With such roles, it has been clear that for the Ly and Tran kings, Buddhism was not only a method, the means for them to attain kingship, but rather, Buddhism has become a joy, a meaning in life, and it was also understandable that Buddhism in the Ly and Tran Dynasties flourishing and developed.

\subsection{The Role of Monks and Pagodas}

Not only did they act as masters to assist the kings in the affairs of ruling the country, the monks of the Ly and Tran Dynasties were also the "guardians" who helped to build and develop Buddhism (Giau, TV 1973; Lang N 1974). There has been no denying that Buddhism was respected and supported by kings to have certain advantages to develop, but Buddhism's internal force must also equip itself with the necessary requirements to meet social demands. Having monks ordained "National Masters" is a great advantage for Buddhism to have an opportunity to develop.

\footnotetext{
${ }^{5}$ According to the book "Lich Trieu Hien Chuong Loai Chi" (Chu, NH 1960), the period from 1600 to 1774 Vietnam was divided into two. The boundary of the dissociation was the Ranh River (Quang Binh province today). In the North of the Ranh River, it was called "Dang Ngoai" by King Le and Lord Trinh. In the South of Ranh River, it was called "Dang Trong" by Lord Nguyen.
} 
Monks of Buddhism with their wisdom and morality also make Buddhism gain the trust of the people and Buddhists. The construction of pagodas in many places by the Ly, Tran, Le, and Nguyen dynasties, supporting the people to become monks, sent envoys to the "North" (China) to ask for sutras, engraving and printing Buddhist scripture, build a house to contain Buddhist scriptures, casting bells, carving statues, etc. had made Buddhist activities at that time very exciting and lively. It was not only meaningful to Buddhism but by the figures of the development, Buddhism has reconciled and entered society as an inseparable entity (Lang, N 1974), Buddhism and the harmonious life, the two sides work together for development. Buddhism has also come from life, Buddhism helped life is also helping themselves, life helped Buddhism is also bringing Buddhism to life, to sentient beings.

The pagoda is the base for the activities religion and propagation of Buddhism of monks and nuns (Giau, TV 1973; Lang, N 1974). Everyone, both Buddhists and non-Buddhists can visit the pagoda, listen to sutras or practice Buddhist rituals. Reading documents on the history of Vietnamese Buddhism (Lang, N 1974), it must be acknowledged that the educational role of pagodas in Vietnam has been largely focused on spiritual-moral education rather than social knowledge. It could be said that the Vietnamese Buddhism of the Ly Dynasty and the Tran Dynasty is the most flourishing (Don, LQ 1995). At that time, although Buddhism was considered the state religion, Buddhist education mainly focused on Buddhist morality and spiritual beliefs. Social knowledge was rarely taught to believers except for the few monks who understand Confucianism follow it.

In order to spread the faith, the Buddha Dharma and educate the Buddha's teachings, many temples have carved and imprinted Buddhist scriptures, creating woodblock prints of Buddhist scriptures that valuable (Su, N 2016). Therefore, the pagodas that have considered centers of culture, also education morality for human, community cultural activities, more than to spread the spirit of compassion, happiness, equanimity, and altruism in life. With the exception of a small number of Zen masters, including monks and nuns, who could reach high spiritual levels, most Buddhists still practice Buddhism at the house or go to the pagoda (Duy, ND 1999).

The Buddhist spirit is still strongly influential among the rulers and kings of the Ly and Tran Dynasties (Lang, N 1974), so the social policies reflect Buddhist morality. By the Le Dynasty and the Nguyen Dynasty, Buddhism was not respected by the court and Buddhism reverted to its starting point in folk people (ordinary people). With ordinary people, the pagodas continue to contribute to moral education and guide spiritual-cultural life. In general, the pagodas in Vietnam at the time of prosperity also partly met the moral life and spiritual beliefs of the Vietnamese people.

\subsection{The Policy of the Vietnamese Government to Buddhism}

Vietnam is a country with many religions and different types of beliefs, according to the Report of the Ministry of the Interior of Vietnam (2015) on summarizing 10 years of implementing the Ordinance on Beliefs and Religions, Vietnam has 13 religions, 37 religious organizations and 01 01 practice method have been recognized and granted operation registration by the State. According to statistics of the Government Committee for Religious Affairs of Vietnam (2020), there are currently more than 4,600,000 Buddhists. As of June 2016, the Vietnam Buddhist Sangha has 63/63 Provincial Buddhism Administration Committees; there are 49,493 monks, nuns. It is the support of the Vietnamese government that has created conditions for Buddhism to continue its development. 
Before 1990, a number of religious policies were inadequate, even with a section of officials who displayed religious disdain, making it difficult for religious activities to consider religious people as abnormal. At that time, wishing to become a monk must register for temporary residence, but when he registered for temporary residence, he was not allowed by the government to become a monk (Vietnam Buddhism Sangha 2014). However, the later the Government of Vietnam became more and more open to Buddhism. Many large national Buddhist activities took place.

For the first time, Vietnamese Buddhists and Vietnamese have witnessed large-scale and massive Dharma activities not only in terms of morality but also in the promotion and preservation of cultural identities of Vietnam (Vietnam Buddhism Sangha 2014). On April 9, 2009, in Kon Tum province held a Refuge Ceremony with 4,000 ethnic people that were Vietkings Center set a record .On July 26, 2011, in Binh Phuoc province held a Refuge Ceremony with 5311 ethnic people, which were Vietkings Center set a record. In Can Tho also held a Refuge Ceremony with 700 Kinh people and Chinese at Phuoc Long pagoda on the occasion of the Buddhist Guiding Workshop. Especially, in Lang Son, every year, a great celebration for the Buddhists aged from 70 to 100 years old on January 13 every year, has become the cultural beauty of the locality.

In 2008, the Vietnamese Government hosted and organized successfully the UN Vesak Celebration with the theme: "Buddhism's dedication to building a fair, democratic and civilized society" which took place at Hanoi. It is the largest Buddhist event in more than 2000 years of history of Vietnamese Buddhism. In 2014, the second UN Vesak Celebration took place in Vietnam with the theme "Buddhism contributes to the achievement of the goals of UN Millennium development" which took place at Bai Dinh pagoda in Ninh Binh province. Vesak 2014 was successfully held with the participation of delegates from 95 countries and territories around the world.

In 2019, Vietnam continues to host the third Vesak celebration at Tam Chuc pagoda in Ha Nam province with the theme "Buddhist approach to global leadership and shared responsibility for a sustainable society ". UN Vesak Celebration has been not only an important event of Buddhism but also for the country and the people of Vietnam. Venerable Thich Quang Thanh - Deputy SecretaryGeneral of the National Organization Committee in charge of the Vesak 2019 Ceremony shared: "Attending Vesak 2019, there are more than 1,650 delegates representing 112 countries. Countries with a large number of participants were: Sri Lanka 178 delegates, India 169 delegates, China 99 delegates, Bangladesh 49 delegates, USA 47 delegates".

In honor of the values of Buddhism heritage, in addition to facilitating religious activities such as rebuilding and repairing temples, organizing annual festivals, the Vietnamese government recognizes the value of Buddhism's heritage through the state administrative documents, specifically:

There were 788 pagodas ranked as national monuments out of 3,374 monuments of the whole country (Statistics of the Department of Cultural Heritage, Ministry of Culture, Sports and Tourism of Vietnam 2012). Among them are the temples recognized as special national monuments such as Dau pagoda, Phat Tich pagoda, But Thap pagoda (Bac Ninh province today); Thay pagoda, Tay Phuong pagoda, Huong pagoda (Hanoi today), Keo pagoda (Thai Binh Province today), etc.

Many Buddhism festivals have been recognized as intangible cultural heritage of the country such as Huong pagoda festival (Hanoi today), Yen Tu festival (Quang Ninh province today), Keo 
pagoda festival (Thai Binh province today), Vinh Nghiem pagoda festival (Bac Ninh province today), Bai Dinh pagoda festival (Ninh Binh province), etc.

For the woodblocks of Buddhist scriptures at Vinh Nghiem pagoda: recognizing that this is a particularly precious heritage of Buddhism, the Vietnamese government has prepared a dossier to be submitted to UNESCO for recognition as a world heritage document. On May 16, 2012, at the Amari Watergate Hotel and Conference Center, Bangkok (Thailand), the Asia-Pacific Commission of UNESCO had officially named and officially recorded the woodblocks of Vinh Nghiem pagoda, Tri Yen commune, Yen Dung district, Bac Giang province is listed as a Documentary Heritage in the World Memory Program.

\section{A few Comments}

In perspective of access to culture, religion is also culture (Vuong, TQ 1989). According to Tran Quoc Vuong (1989), "at the center of every major religion has a philosophical nucleus, have humanitarianism - the greatest cultural achievement of mankind. The "compassion" of the Buddha, the "charity" of Christ, benevolence, and righteousness of Confucianism are cultural pearls". From the viewpoint of the history of birth and maturity, religion has been both a product of culture and an organic component and a constituent element of culture". Thus, Buddhism itself was an element of human culture, the creations of Buddhism are cultural creations. The heritage that Buddhism leaves in the places it goes through will become cultural. Of course, not all of the legacy of Buddhism will become cultural. Only the heritage of Buddhism in accordance with the virtues, beliefs, habits of the land and people that it exists, the legacy it leaves can become a cultural heritage of that nation, specifically:

Buddhism has been both religious and ideological and cultural, having had a profound impact on the social life of Vietnam for thousands of years. Introduced in Vietnam from the 2nd century AD (Giau, TV 1973; Thu, NT 2008), Buddhism existed mainly at the psychological level and religious culture rather than a strict system of rules and institutions. The vast majority of people do not recite Buddhist scriptures other than the words "Namo Amitabha Buddha" or "Namo Guan Yin Bodhisattva", but they all feel very contented, heading towards Buddha with the deep belief that all suffering and uncertainty will be eradicated. This has been attempted by Tran Van Giau (1973) affirmed, "Buddhism is popular among the people. People do not know anything about the Buddha's high philosophy but only pray for blessing, retribution, and reincarnation only. For a long time, Buddhist philosophy became a kind of ethical compassion, charity, suffering, salvation, and sentient beings could understand and do it, not so far away and troublesome as Buddhist philosophy primitive. Cultivate yourself, accumulate virtue in this life to be happy, enjoy happiness in the next life".

Buddhism, when introduced into Vietnam, was more or less localized. Buddhism has merged with folk beliefs and other religions, along with indigenous culture to create a diverse cultural and religious activities. The intersection between exogenous religion and indigenous beliefs reflects the process of cultural exchange and acculturation, in which nationality and internationality are always intertwined.

Buddhism basically tends to "live in peace" with other religions. In Vietnam, the phenomenon of religious mixed and reconciled (Confucianism - Buddhism - Taoism) is determined by scientists 
to be a prominent feature of culture in general and Buddhist culture in particular (Giau, TV 1973; Lang, N 1974; Hinh, ND 1999; Thu, NT 2008). When Christianity, Protestantism and Islam appeared, the religions in Vietnam still existed in parallel in peace, having a common purpose of contributing to the development of the country.

Vietnam distilled from the Buddhist philosophy the factors suitable to the country's sociohistorical conditions to create the quintessence of national culture, When researching Mau Tu, Le Manh That (1999) commented: "Buddhist philosophy is seen as a "road", at home it can be used to worship the parents, if a king can use to rule the people, standing alone can teach himself". The ethical culture of Buddhism contributes to the creation and encouragement of human love and pride (Thuan, NK 2004), which makes us more concerned with the well-being of others, within the family and community and beyond are all of humanity. Compassion and wisdom in Buddhism have become nourishing materials, helping the mind to be peaceful and happy, so it has the ability to connect people's hearts and social solidarity.

Faith is one of the most valuable spiritual values Buddhism brings to Vietnamese people (Lang, N 1974). "Buddhism is a religion of faith but not beliefs in God but beliefs in people, in the minds of people who judge right and left, in the hearts of people who love others, in the human will to reach the best. That faith strengthens the spirit of independence and self-reliance of the Vietnamese people, does not submit to the power and willingness to sacrifice for the independence and freedom of the country, because of the sovereignty and territorial integrity of the nation" (Giau, TV 1973). With the ability to "connect with the world" and "accompany the nation", Buddhism has made important contributions to the cause of national construction and defense of Vietnam (Thuan, NK 2004). Every time the country had foreign invaders, many monks abandoned their monk's robe, holding weapons and the country's army and people to fight the enemy to protect the country (Hinh, ND 1999). In some historical periods, Buddhism has exerted influence as a "source of energy" to promote development, even dominating the ideology, literature, and art of the country as under the Ly and Tran Dynasty, from the 10th century to the 14th century.

From the above cultural characteristics, it can be affirmed that, in the history of thousands of years of introduction into Vietnam, Buddhist culture has been deeply rooted in the national culture and played a great role in uniting the heart of Vietnamese people. Buddhism has a great role in uniting people and national solidarity, effective "filter" (Giau, TV 1973) against cultural assimilation and preserving Vietnam's cultural identity and diversity. The Buddhist heritage has become the inseparable heritage of Vietnamese culture.

\section{Conclusion}

In Vietnam, Buddhism was present very early, and accompanied the people throughout the history of nation-building, defending and developing the country for more than 2000 years, since Buddhism was introduced into Vietnam. In Vietnam, Buddhism has been localized and continuously localized, becoming an important part of the spiritual life of Vietnamese people. Buddhist culture is an inseparable part of Vietnamese culture (Government Committee for Religious Affairs 2014).

Vietnamese Buddhism not only carries within itself the universal essence of Buddhism in the world, but is also nationalistic to Vietnamese people. The historical fact has vividly demonstrated 
that Buddhism has harmonized, supported and contributed to the building of a stature Vietnamese culture with great achievements in all fields of social life. From customs, traditions, beliefs, rituals, festivals to architecture and sculpture; from history, religion, literature to painting, music, Zen, etc. In that, we can see that literature, thought and Buddhist temples are areas of great achievements; have been intimately involved and supporting the spiritual life of Vietnamese people for over 2000 years.

In order to affirm the role of Buddhism in general and Buddhist cultural heritage in particular in contemporary Vietnamese society, President of the Socialist Republic of Vietnam - Nguyen Minh Triet spoke at the opening ceremony of the UN Vesak Celebration (2008) in Hanoi: "Vietnam is a multi-religious country where Buddhism is a religion that existed very early, 2000 years ago. Right from the very first day, with the thought of being compassionate and humane, Buddhism has been well received by the Vietnamese people, always accompanying the people with compassion, happiness and attachment between religion and life, striving for happiness, peace for humans. In all eras, Vietnamese history has always recorded great virtue and great monks helping out and defending the people and nation".

Funding: This research is funded by University of Transport and Communications (UTC).

Conflicts of Interest: The authors declare no conflict of interest.

\section{References}

Anh, T. 2005. The custom of worshiping in families and public places in Vietnam. Hanoi: Youth.

Bang, H. 1970. “Our Ancient Printing Technique”. Journal of Historical Studies 133, pp. 25 - 31.

Binh, PK. 2005. Vietnamese custom. Hanoi: Culture Information.

Bhikkhu, Bodhi. 2000. The Samyutta-Nikāya, the connected discourses of the Buddha. Boston: Wisdom.

Bien, TL. 1989. “The Walk of the Vietnamese Pagoda”. Journal of Architecture 2 (8), pp. 30-36.

Bien, TL. 1996. Vietnamese pagoda. Hanoi: Cultural Information.

Brown, Percy. 1959. Indian architecture. Bombay: Taraporevala.

Cam, HH. 2006. "First Step to Learn about Vietnamese Traditional Paper Profession". Han Nom Journal 19 (3), pp. 17 - 23.

Chu, PH. 1960. Lich Trieu Hien Chuong Loai Chi. Hanoi: History.

Cohn, W. 1925. Buddha in der Kunst des Ostens. Leipzig.

Dai Viet Su Ky Toan Thu. 1697; Translation: 2004. Vol 1. Hanoi: Social Sciences.

Dai Viet Su Ky Toan Thu. 1697; Translation: 2004. Vol 2. Hanoi: Social Sciences.

Don, LQ. 1995. Toan Viet Thi Luc. Hanoi: Social Science.

Duy, ND. 1999. Buddhism with Vietnamese culture. Vietnam: Hanoi.

Giau, TV. 1973. The development of thought in Vietnam from the nineteenth century to the August Revolution. Hanoi: Social Siences. 
Giap, TV. 1968. Buddhism. Hanoi: Board of Library, Van Hanh.

Hai. TT. 2002. Basic Buddhism studies Vietnam: Ho Chi Minh City.

Harvey, Peter. 2012. An introduction to Buddhism, teachings, history and practices. Cambridge: University Press.

Herb Stovel, Nicholas, Stanley Price and Robert Killick. 2013. Conservation of living religious heritage. Rome: Ugo Quintily S.p.A

Hinh, ND. 1992. Ancient tower of Vietnam. Hanoi: Social Science

Hinh, ND. 1999. Vietnamese Buddhism thought. Hanoi: Social Science.

Hong, M., Mui, NH. 1986. "Understanding our Printing Profession through the Han Nom Bookstore". Han Nom Journal 1 (1), pp. 14 -18.

Hue, NT. 2016. "Vietnam's Nguyen Dynasty Woodblocks, a World Heritage Document". Xua and Nay Journal 474 (8), pp. 52 - 56.

Lan, TC. 2005. Buddhism Architecture through the Ages. Falun Practice, Number 12, February.

Lang, NB. 1972. Vietnamese Buddhism architecture. Saigon: Van Hanh University Institute.

Lang, N. 1974. Vietnamese Buddhism commentary. Saigon: Laboi.

Ly, C and Giang ĐL. 2016. Buddhism literature is the source of erudite literary and written literature of Vietnam. Hanoi: Social Science.

Malalasekera, GP. 1962. Founder editor-in chief, encyclopaedia of Buddhism. Vol 8. Sri Lanka: Published by the Department of Buddhist Affairs, Ministry of Buddha Sasana.

Michell, George. 1989. The Penguin guide to the monuments of India, Vol 1. London: Viking.

Nguyen, P. 2019. "Buddhism and Its Influence under the Tran Dynasty". The Government Committee for Religions Affairs. Available at:

http://btgcp.gov.vn/Plus.aspx/vi/News/38/0/240/0/2250/Phat_giao_va_nhung_anh_huong_cua _Phat_giao_duoi_thoi_Tran

Ngoc, P. 2002. Vietnamese cultural identity. Hanoi: Literature.

Quang, TT. 2008. Buddhism entered and played development. Hanoi: Religion.

Quang, T and An, T. 2019. "Luy Lau Citadel: Closer to the present". Light ray Journal. Available at: http://tiasang.com.vn/-khoa-hoc-cong-nghe/Thanh-co-Luy-Lau-Gan-hon-toi-hien-thuc--15254

Prebish, Charles and Tanaka, Kenneth. 1998. The faces of Buddhism in america. Berkeley: University of California Press.

Schnitger, FM. 1937. The Archeology of Hindu sumatra. Leyde: Dacca.

Stepaniants, MT. 2003. Philosophy of the orient. Hanoi: Social Science.

$\mathrm{Su}$, N. 2016. "About the Process of Traditional Woodblock Printing in Vietnam". Cultural Heritage Journal 3 (56), pp. 22 - 27. 
Tadgell, Christopher. 1990. The history of architecture in India. London: Phaidon Press.

Tam, TG. 2014. "The Teachings of the Sangha". Journal of Buddhist Studies 15 (1), pp. 26 - 31.

That, LM. 1999. Research of Thien Uyen Tap Anh. Vietnam: Ho Chi Minh City.

Tho, HT. 2010. "Buddhism with National responsibility in History and Today". Journal of Buddhism Studies 2 (11), pp. 10 - 18.

Thuan, NK. 2004. Generalizing Vietnamese culture history. Hanoi: Educaiton.

Tuong, VV; An, LTT. 2019. Pagoda in Vietnam. Hanoi: Thong Tan.

Thu, NT. 1988. Vietnamese Buddhism history. Hanoi: Social Sciences

Tru, CQ. 1998. Art of Ly - Tran Dynasties, Buddhism art. Hue: Thuan Hoa.

Vietnam Academy of Social Sciences. 1993. Vietnam pagoda. Hanoi: Social Sciences.

Vietnam Buddhist Sangha. 2014. Proceedings of the 7th national Buddhism delegation congress. Hanoi: Religion.

Vuong, TQ. 1989. Religious Culture. Catholic and ethnic 1 (6), pp. 28 - 35. 